\title{
ADVISORY MANAGEMENT IN THE FIELD OF HIGHER EDUCATION: DIRECTIONS AND MODELS
}

\author{
Olga Marchenko ${ }^{1}$, Liudmyla Radchenko ${ }^{2}$, Hanna Guzenko ${ }^{3}$, Nadiya Kryvosheeva ${ }^{4}$, \\ Tamila Shcheblykina ${ }^{5}$ \\ 'Department of Economic Theory, Yaroslav Mudryi National Law University, Kharkiv, Ukraine \\ ol.mar4encko2011@ukr.net \\ ORCID: http://orcid.org/0000-0003-4761-9620 \\ ${ }^{2}$ Department of Tourism and Social Humanities Sciences, Kharkiv College of Trade and Economics Kyiv National University of Trade \\ and Economics, Kharkiv, Ukraine \\ kharkiv@htek.com.ua \\ ORCID: http://orcid.org/0000-0002-2514-7549 \\ ${ }^{3}$ Department of Economics, Management and Administration, Kharkiv College of Trade and Economics Kyiv National University of \\ Trade and Economics, Kharkiv, Ukraine \\ GuzenkoGanna@gmail.com \\ ORCID: http://orcid.org/0000-0002-4743-4821 \\ ${ }^{4}$ Department of Economics, Management and Administration, Kharkiv College of Trade and Economics Kyiv National University of \\ Trade and Economics, Kharkiv, Ukraine \\ predkisila@gmail.com \\ ORCID: http://orcid.org/0000-0002-2790-9076 \\ ${ }_{5}^{5}$ Department of English Language, H. S. Skovododa Kharkiv National Pedagogical University, Kharkiv, Ukraine \\ Tamila.shch@gmail.com \\ ORCID: http://orcid.org/0000-0002-7135-3757
}

ARTICLE INFO

Article history:

Received date 12.05 .2020

Accepted date 12.06.2020

Published date 30.06.2020

Section:

Educational Policy \& Reform

D O I

$10.21303 / 2313-8416.2020 .001338$

\section{KEYWORDS}

management of higher education improvements

advisory management

models of the advisory process
A B S TRACT

The Object of Research: management of higher improvements and advisory services, aimed at achieving the program outputs of the educational process by creating conditions for effective advisory support for applicants and staff of educational institutions.

The issue to study: the introduction of measures and methods of advisory management in the quality of higher education management.

The Main Scientific Results: the conceptual bases of advisory management as a system of principles, measures and methods of advisory management are revealed. Based on the subject approach, the models of the advisory process in higher education institutions are identified and characterized, the effectiveness of combining the models of internal and external counseling to ensure the quality of higher education is proved.

The Area of Practical Application of Research Outputs: higher education institutions and institutions managing higher education.

Innovative technological product: on the basis of the subject approach the technologies of advisory management are revealed. The introduction of these technologies into management of higher education improvements allows to use effectively the opportunities of advisory models of knowledge and information flow to achieve program outputs of educational process.

The field of application of innovative technological product: practice of formation, implementation and development of management system of educational services improvements.

(C) The Author(s) 2020. This is an open access article under the CC BY license http://creativecommons.org/licenses/by/4.0).

\section{Introduction}

\section{1. The Object of Research}

The quality of higher education directly depends on the effectiveness of educational institutions management, in particular, the implementation of activities and methods of advisory management into management practices that is the object of research. The object of research is the management of quality and advisory, which ensure the achievement of program outputs of the educational process based on creating conditions for effective advisory support for both higher education applicants and educational institution staff.

\section{2. The Problem Description}

So far, the advisory management as a component of the business administration hasn't been considered as the object of scientific analysis and generalizations, as far as it appears to be a mana- 
gerial innovation that requires justification, development of measures for implementation in the educational process and effective application. The current stage of research of advisory management by scientists and scholars in the fields of education, management, economics is characterized by the accumulation and generalization of practical experience in applying its principles and methods in the business administration, in particular in higher educational institutions.

\section{3. The solution to the proposed problem}

There are currently several approaches to determining the correlation between management and counseling in an organization, particularly in higher educational institution. Firstly, the advisory management and advisory institutions are being researched. The works by D. H. Mayster [1] are devoted to the definition of nature and advisory management activities. E. Bache analyzes the principles of effective advisory business [2], P. Block researches the factors of success in advisory process [3]. Secondly, the role of advisory in the management of an enterprise as a holistic system as well as separate areas and types of its economic activity are substantiated. V. V. Rovenskaya and K. O. Degtyareva analyze the basics of the use of advisory in personnel management [4], F. Wickham denotes the role of advisory in project management [5]. Thirdly, the management advisory, which role is in improving the management of institutions is revealed by K. Markham [6]. The advisory process in university education is studied by L. S. Shevchenko [7], moreover, advisory factors of education quality are revealed by L. O. Belova, V. G. Bulba and O. V. Postupna [8].

The problem of implementing activities of advisory management into the quality assurance system of higher education can be solved on the basis of substantiation of its conceptual foundations and determination of directions and ways of methods and tools application of professional advisory into the management of the educational process.

The aim of research is to reveal the content and main components of advisory management, which combines management and advisory resources to ensure the quality of education.

\section{Materials and Methods}

The study of theoretical and applied aspects of advisory management of educational institutions was based on a subject-based approach to determining its content and on methods of systematic and structural-functional analysis as well as on a synergetic approach. Based on the modeling method, the advisory models in an educational institution have been developed.

\section{1. The Experimental Procedures}

The research was carried out by studying and generalizing the practice of management improvements and advisory activities in higher educational institutions of Ukraine, in particular at the Yaroslav Mudryi National Law University, Kharkiv College of Trade and Economics, Kyiv National University of Trade and Economics, H. S. Skovoroda Kharkiv National Pedagogical University.

\section{Results}

The importance of introducing of advisory management in the field of education is determined by many factors and reasons, including the widespread application of advisory forms of knowledge transfer in the educational process as well as the important role of professional advisory as a part of modern education quality assurance system.

The research of advisory management of educational institutions was carried out on the basis of a subject-based approach to determining its content, which includes a justification of its main components, directions, models and activities.

According to the subject-based approach, the advisory management is a system of goals, principles, technologies, methods and activities of advisory management in the institution and advisory activities of managers as administrators. The object of advisory management is the flow of knowledge and information into the institution in the form of advisory. The purpose of advisory management in the field of education is to improve the quality and efficiency of the educational process, the competitiveness of educational institutions by providing staff and students with the necessary knowledge and information in a advisory form.

The main managerial units of the advisory management of the educational institution are as follows: 
- management of advisory as a set of management activities, methods, techniques of providing advisory assistance to:

1) the educational institution staff in solving problems of their professional activities;

2) for higher education applicants in the process of their education. Its components are the management of:

a) internal advisory and consulting market of the educational institution;

b) external advisory;

c) a combination of internal and external advisory; d) the advisory process;

- advisory (consulting form) management as an administrative activity of different levels and specialization of the heads of educational institutions with the advice, recommendations to subordinates, advisory on certain issues of their professional functions. So, this is management in the form of advisory. Managers, being administrators of a certain level combine their managerial functions and advisory subordinates in various forms.

The units of advisory management such as the advisory administration and counseling management, are interconnected and interdependent, as far as they are combined, firstly, due to the resource and the object of management, that is knowledge and information in the form of advisory services; secondly, they are combined according to the purpose of management, that is to improve the quality of the educational process, efficiency and competitiveness of the educational institution as a holistic system by providing the necessary knowledge and information in the form of advisory services; furthermore, in accordance with the management result as a competent problem-solving of the institution and its subsystems at different stages of its life cycle.

In terms of content and focus, the advisory management, firstly, is a component of knowledge management in the institution. Its task is to provide the institution with the necessary knowledge and information in the form of advisory services. Knowledge management has general functions: planning, organization, motivation, control of knowledge flows and their participants' actions within the institution and its external intellectual networks. One of its special functions aimed at managing of the formation, application, renewal, protection of knowledge resources of the institution, is the function of advisory management, which is the administrative unit of advisory management.

Secondly, the advisory management is directly related to the connected processes of educational institutions management, such as communications, management decisions and leadership. According to the connected processes of business administration, the main tasks of advisory management are to ensure:

- management decision-taking with information and knowledge resources in the form of professional advice, recommendations, expert opinions, which is an important factor of their validity and effectiveness;

- effective management of the educational administration and its subsystems on the basis of application of advisory activity means. The administrator performs managerial functions within his or her competencies and responsibilities, based on orders, teams, internal regulations, economic methods of employees' incentives and others. No less effective means of influencing the manager on the staff is his or her competent advice to employees on certain aspects of their professional activities. It concerns managerial functions of administrators (linear and functional), whose advice is a way both to encourage subordinates to take certain actions in the interests of the institution, and to ensure the professionalism and efficiency of their functions. Thus, advisory process is a means of leadership;

- productive communications in the process of advisory management and in the implementation of the managers' advisory function.

The educational process involves advisory in various areas, forms, models, which is the object of advisory management. Firstly, educational services in the form of counseling are characterized by:

- direct transformation of the teacher's knowledge into the applicant's knowledge in the process of advisory. So, the effectiveness of the educational process depends on the quality of advisory management;

- students' active participation in the advisory process. The continuity of the provision and consumption of educational services in the form of advisory is characterized by the relationship of 
teacher's and student's actions, their cooperation, which call for its direction by advisory management activities to obtain a certain learning outcome;

- variability of the quality of educational services in the form of counseling, which is determined not only by the teacher's activity that is the form of intellectual product, but also by the effectiveness of student's participation in the advisory process, as well as it call for necessity to manage the advisory process in order to ensure its high quality.

Secondly, the advisory process in an educational institution according to its participants has the following models:

- "a teacher - an applicant for higher education" model. Teaching disciplines involves the use of various forms of the educational process management, such as lectures, seminars and practical classes, workshops and others. An important form is the teacher's advisory tutoring of both a certain student group and an individual applicant for higher education. In the process of counseling, the teacher's knowledge is transformed into the student's;

- "a teacher-a teacher" model, according to which counseling is carried out as an exchange of knowledge between teachers, scientists and scholars in the form of:

a) advice and recommendations, provided by teachers;

b) discussions, round tables, scientific and methodical seminars of departments, interdepartmental seminars, conferences devoted to certain scientific and educational problems;

- "an administrator-a subordinate" model, according to which advisory service is additional but important function of the heads of educational institutions at different levels of management hierarchy. They not only define certain tasks to subordinates, but also explain their activities and evaluation criteria but they also provide advice and recommendations. Administrative models of institutional communications in the form of advisory are business negotiations, leaders' speeches at meetings and conferences, instructing of subordinates, issuing orders, directives, instructions, etc. Advisory activity as an institutional communication is an administrative technology with business conversation as a direct communication between a manager and a subordinate as the most common type. The participants seek to achieve certain goals: a manager aims at improving the performance of subordinate's functions and a subordinate aims to understand manager's requirements, tasks, technologies and results of their implementation. Depending on the purpose, a business negotiation can be aimed at clarifying the nature of the problem situation and identifying its causes; a search for possible ways and means to get out of this situation, overcoming the difficulties and arising obstacles; establishing effective relations between the participants or improving these relations; taking important management decisions, etc.;

- "specialists-employees" model, which provides for the definition of advisory process as an important area of educational institution functional services.

Administrative forms of advisory according to the "a specialist - employees" model differ in the level of adviser's independence, forms of his or her responsibility and motivation as well as the nature of economic relations between advisers and departments of the institution:

1) The advisory as a function. Professionals and managers of the educational institution, performing professional activities, combine functions directly aimed at the performance of their duties and advisory on issues within their competence. Therefore, an important area of their professional activity is advisory. Advisory-function, on the one hand, is the most common and most accessible form of advisory; on the other hand, it has certain professional and time limits. Due to the fact that advisory is not the main, but concomitant (complementary) function of specialists and managers of the educational institution, its implementation is usually insufficiently motivated, is unsystematic as well. In addition, such advisers do not have the necessary advisory skills or time to perform it. Therefore, this organizational form of advisory can be effective only to consider current issues related to the implementation of certain activities of the educational institution;

2) The advisory as a profession. The advisory department ensures the continuity of the advisory process in the educational institution. Compared to the advisory function, the advisers have a higher level of professionalism and motivation, as the provision of advisory services is their main activity and direct responsibility, not an additional function. The advisory department is a service center, which activity is evaluated on the basis of the quality of provided services and the term of their performance. The expenses associated with the activities of the advisory department are a part of the total expenses of the educational institution. However, since a full-time adviser or 
advisory department employee are hired workers getting salaries and whose activities are subject to administrative management, it is possible, firstly, to involve them in the performance of not only advisory process but also to take other functions that are not their direct duties. Secondly, the consequence of the availability and advisers" "free" services for employees and departments of the educational institution is their excessive use reducing the quality of advisory.

3) A higher level of independence and efficiency of advisory is provided by advisory departments such as the responsibility centers. They provide a certain adviser's autonomy in taking current decisions, increase their responsibility and strengthen motivation. The advisory departments, such as centers of responsibility, help to overcome the situation with advisers' excessive use, limit their involvement in quasi-consulting activities, increase the responsibility of advisers, employees and departments using their services.

The management of advisory according to the «a specialist-employees" model is focused on choosing an effective administrative form of advisory, due to many factors, including the nature, scale and structure of the educational institution, the stage of its life cycle, financial opportunities, tasks its leadership faces, the level of staff qualification, the availability of intellectual resources, the degree of its innovative activity.

A comprehensive model of the advisory process in an educational institution is the "a combination of internal and external advisory" model. According to the criterion of the knowledge source required by the educational institution, there are internal and external advisory of its staff. The task of advisory management is:

- to choose services of internal or external advisers, which involves the analysis of their strengths and weaknesses;

- to combine services of internal and external advisers in order to solve the problems of the educational institution. Internal and external advisory is complementary network for the institution to receive professional consulting assistance in solving current and strategic innovation problems. The choice in favor of internal consulting does not exclude the possibility and necessity to use the market network to obtain specialized knowledge and information and vice versa. The most effective model for the institution to receive professional advisory is a model that combines external and internal advisory, market and internal networks of professional knowledge and information;

- management of knowledge flow in an advisory form in an educational organization. The turnover of advisory services within the educational institution, firstly, is the object of administrative management, which is fully applied in the use of such administrative forms of internal advisory as advisory-function, advisory-profession, and advisory-department. In addition, the internal advisory market is regulated by agreements between internal advisers and departments using their services. The advisory manager relies in its activity on the analysis of the external market of advisory services as a source of information for making decisions about the volume and structure of the internal advisory market, the level of advisers' wages, and internal prices for advisory services.

The internal advisory market is a means of replacing the services of the external market of advisory support for an educational institution. Its development enhances the institution's ability to meet the needs for professional knowledge and information.

\section{Discussion}

As a result of the research, the subject approach to the definition of advisory management of educational institutions as a comprehensive managerial process aimed at providing qualitative advisory and effective implementation of the advisory function of heads of educational institutions is substantiated in the article. So far, in scientific and applied resources on advisory management, specialized and psychological-managerial approaches are used to determine its content. In comparison to other approaches the proposed subject approach has certain advantages:

1) highly specialized approach: advisory management is interpreted as the activity of advisers to facilitate effective management decisions to be taken on investment projects by the clients [9]. The advantage of the subject approach firstly, is the substantiation of the conceptual foundations of advisory management, which allows to apply its principles and methods in any field of economics and management; secondly, a comprehensive description of advisory management in the field of education; 
2) psychological and managerial approach: advisory management is defined as:

a) advisory leadership style in the institution, consultative-democratic system of leadership according to the classification of R. Lakerate [10];

b) a method of managerial decision making [11];

c) an advisory function of the manager, a way of his or her influence on subordinates [12].

The advantage of the subject approach is the interpretation of the content of advisory management as a consulting management and advisory function of managers, which is considered to be the basis for defining its tasks, areas of implementation and development as part of the overall management of institutions.

Further research of advisory management will be aimed at revealing the models of external advisory management of educational institutions as a source of knowledge and information, a means for educational mobility.

\section{Conclusions}

Advisory management in the context of the subject approach is a management innovation aimed at ensuring the high quality of the educational process based on the use of methods and means for managing of advisory activities and the implementation of the advisory function of educational institutions managers. The tasks of advisory management are the development, implementation and effective management of models of the advisory process, ensuring the synergetic effect of all forms, types and models of advisory in the educational institution. An important function of advisory management is the regulation and coordination of advisory departments and advisers, regulation of the internal market of advisory services, management of advisory expenses and others.

The introduction of advisory management in the practice of educational institution management will ensure the achievement of program outputs of educational and professional programs for training specialists and professionals in various fields of knowledge as well as to increase the efficiency of internal quality assurance and competitiveness of higher education institutions in the market of educational services.

\section{References}

[1] Maister, D. H. (1993). Managing the Professional Service Firm. Oxford: Simon and Schuster, 368.

[2] Beich, E. (2006). Konsaltingovii biznes: osnovy professionalizma. Saint Petersburg: Piter, 272.

[3] Blok, P. (2007). Bezuprechnii konsalting. Saint Petersburg: Piter, 298.

[4] Rovenska, V. V., Dehtiarova, K. O. (2015). Osnovy vykorystannia konsaltynhu v upravlinni personalom. Hlobalni ta natsionalni problemy ekonomiky, 4, 556-561.

[5] Uikkhem, F. (2006). Konsalting v upravlenii proektami. Moscow: Delo i Servis, 367.

[6] Markkhem, K. (2005). Konsalting menedzhmenta, ili Kak uluchit svoi biznes. Moscow: Fair-Press, 392.

[7] Shevchenko, L. S. (2016). Universytetska osvita: ekonomichni priorytety ta upravlinnia rozvytkom. Kharkiv: Pravo, 188.

[8] Bielova, L. O., Bulba, V. H., Postupna, O. V. (2018). Stan i problemy zdiisnennia upravlinnia yakistiu osvity ta osvitnoi diialnosti v Ukraini: ekspertne otsiniuvannia. Teoriia ta praktyka derzhavnoho upravlinnia, 2, 8-17.

[9] Chen, J. (2019). What Is Advisory Management? Available at: https://www.investopedia.com/terms/a/advisory-management.asp

[10] Koncepciia liderstva po Laikertu. Available at: https://hrhelpline.ru/kontseptsiya-liderstva-po-lajkertu

[11] Konsultativnii menedzhment. Available at: https://vocabulary.ru/termin/konsultativnyi-menedzhment.html

[12] Konsultativnii menedzhment. Available at: https://scicenter.online/osnovy-menedjmenta-scicenter/konsultativnyiy-menedjment. html 